\title{
Prevalence of Cystic Echinococcosis in One-Humped Camels Slaughtered at Addis Ababa Municipality Abattoir, Ethiopia
}

\author{
Natnael Abebe ${ }^{1}$, Biruhtesfa Asrade ${ }^{2}$,Berhanu Mekibib ${ }^{* 3}$ \\ ${ }^{1}$ Field Veterinarian, Addis Ababa, Ethiopia \\ ${ }^{2}$ College of Agriculture and Environmental Sciences, Department of Veterinary Medicine, Bahir \\ Dar University, P.O. Box 79, Bahir Dar, Ethiopia. \\ ${ }^{3}$ Faculty of Veterinary Medicine, College of Natural and Computational Sciences, Hawassa Uni- \\ versity, P.O. Box 05, Hawassa, Ethiopia; Phone: +251-92630-8148 \\ ${ }^{*}$ Correspondent author: Dr. Berhanu Mekibib; E-mail address: berhanumm2002@gmail.com,
}

\begin{abstract}
Cystic Echinococcosis (CE) is one of the most important zoonotic and economically important disease prevalent in different parts of Ethiopia and the world at large. This survey aimed to estimate the prevalence, identify associated risk factors, and tissue distribution patterns of $\mathrm{CE}$ in camels slaughtered at Addis Ababa municipality abattoir. Out of 416 one-humped camels examined during meat inspection, hydatid cysts were detected in 159 (38.22\%) of them. The cyst was detected more frequently in the lungs (37.02\%) followed by liver (35.1\%), but very few camels had cysts in their heart, spleen, and kidneys. Significantly higher $(p<0.05)$ prevalence of hydatid cyst was observed in female than male camels $(48.05 \%$ vs $32.4 \%)$, in adult camels than young ones $(53.1 \%$ vs $20.2 \%)$, and camels with good (25.0\%) and medium body conditions (67.4\%) compared to those in poor body condition (7.7\%). The study further revealed that out of 768 cysts collected from the different organs, $169(22 \%), 215(28 \%)$ and 384 $(70.57 \%)$ were abscessed/calcified, sterile and fertile cysts, respectively. About $54 \%(\mathrm{n}=235)$ of the cysts in the lungs and $45 \%(\mathrm{n}=148)$ in the liver were fertile. Of which, $146(62.13 \%)$ cysts in lungs and 87 (58.78\%) cysts in liver were viable. In conclusion, this study revealed a high prevalence of $\mathrm{CE}$ with a higher proportion of fertile and viable cysts in the pastoral areas. Therefore, to reduce the wide spread occurrence of $\mathrm{CE}$ and hence the presumed public health and socio-economic impacts, extension work on safe disposal of infected offal and dead animals, awareness creation to the community about the disease, construction of abattoirs with appropriate disposal pits and strict meat inspection should be given due consideration.
\end{abstract}


Keywords: Abattoir; Camelus dromedarius; Cystic echinococcosis; Prevalence; Risk factor.

\section{Introduction}

The one humped camel (Camelus dromedarius), by the virtue of their excellent adaptive behavior, play significant role in the livelihood of pastoralists living in most arid and semi-arid countries of the tropics including Ethiopia. It is almost everything to pastoralistsas source of food and power, cash and prestige, and means of storing wealth (Zeleke and Bekele, 2000). Moreover, quite huge numbers of camels are also slaughtered in the capital city and some towns in the eastern and south eastern part of the country. At the moment camels are also becoming one of the export animals to Arabian Peninsula and Egypt (SOSSahel Ethiopia, 2007; Tefera and Abebe, 2012).

Despite their significant socio-economic contributions, camels in the pastoral areas of Ethiopia are still facing shortage of water, feed, housing and health care services (Zeleke and Bekele, 2000; Keskes et al., 2013; Regassa et al., 2015). Their natural semi-arid to desert habitats, together with the poor husbandry practice, are known to induce severe stress conditions in camels and ultimately make them susceptible to many diseases and ailments (Abbas et al., 1993; Volpato et al., 2015). Moreover, the broader home range of the camel in pastoral areas, the poor veterinary service and improper disposal of offals and cadavers are known to exposes the camel to various pathogens including eggs of parasites. Specifically, the large number of dogs kept by the pastoralist and the wild carnivores freely roaming in the area can potentially contaminate the communal watering points and the pasture with eggs of Echinococcus granulosus (Elham et al., 2014)

Cystic echinococcosis (CE), caused by the cestode parasite called Echinococcus granulosus, is one of the most important zoonotic and economically important diseases prevalent in different parts of the country and the world at large (Dalimi et al., 2002; Ito et al., 2003; Latif et al., 2010; Ibrahim 2010). Cystic echinococcosis affects most livestock including cattle, sheep, goat, pig and camel and induces significant economic loss through organ condemnation, decreased hide value, carcass weight, and decreased productivity (Oryanet al., 1994; Dakkak, 2010). Because of lack of satisfactory test to diagnose CE in living livestock (Craig, 1997; Njoroge et al., 2002), the diagnosis is mainly dependent on meat 
inspection in the abattoirs (Njoroge et al., 2002; Acosta-Jamett et al., 2010; Ibrahim, 2010).

Based on several cross-sectional studies conducted in Ethiopia and abroad, cattle, sheep and goats appear to be the most common intermediate hosts for Echinococcus granulosus; recent studies in Sudan and Turkana however suggest that camels are equally important intermediate host (Omer et al., 2004). In Ethiopia, except the few previous reports (Woldemeskel et al., 2001; Muskin et al., 2011; Boru et al., 2013; Hayer et al., 2014; Debela et al., 2015; Regassa et $a l ., 2015)$ information available on CE in camels is limited to small part of the country and are fragmented to conclude on the role of camels in the epidemiology of the disease. Therefore, the present study was designed to estimate the prevalence, identify associated risk factors, characterize the cyst and illustrate its tissue distribution in camels slaughtered at Addis Ababa municipality abattoir, Akaki branch.

\section{Material and Methods}

\section{Study Area}

The study was conducted from October 2018 to May 2019 at Akaki abattoir, which is owned by the Addis Ababa abattoir enterprise and located in Addis Ababa city. The city is located at $9^{\circ} 1^{\prime} 48^{\prime}$ North and $38^{\circ} 44^{\circ}-24^{\prime}$ East at an average altitude of 2,500meters above sea level. Although the camel meat is not widely known in Addis Ababa, camels are slaughtered for the Somali and other Muslim communities who live or stay for short in the city (Salih et al., 2011). The camels slaughtered at the abattoir were originated from Borana and Kereyu pastoral areas and Minjar-Shenkora district.

Borana pastoral area is located at approximately $600 \mathrm{kms}$ South of Addis Ababa at an altitude ranges from 970 meters above sea level in the south bordering Kenya to 1693 meters above sea level in the Northeast. The area is characterized by an arid and semi-arid climate, with pockets of sub-humid zones. The rainfall in the area is bimodal where the average annual rainfall varies between $350 \mathrm{~mm}$ and $900 \mathrm{~mm}$. The rainfall of the area is erratic by nature and there are four distinct seasons interspersed by long rainy season (expected between March and May) and the short rainy season (between October and November) (Galma, 2015). 
Kereyu Pastoral area, circumscribed in Fentale district, is located at about 250 $\mathrm{km}$ East of Addis Ababa at an altitude of 930 meters above sea level. The tribes of Kereyu pastoralist occupy the arid lands around the Awash River down in the rift valley for pasture for their cattle, goats and camel (Tefera and Abebe 2012). The area has an average annual rainfall of $504 \mathrm{~mm}$. The mean annual maximum and minimum temperature are 32.40 and $18.5^{\circ} \mathrm{C}$, respectively. Pastoralism and agro-pastoralism are the main livelihood systems in the area (Beyene and Gudina 2009).

Minjar-Shenkora is one of the districts in the Amhara Regional state of Ethiopia, located at the southern end of the North Shewa Zone at about $129 \mathrm{~km}$ East of Addis Ababa. The district is bordered on the east, south and west by the Oromia Regional state and on the northwest by Hagere Mariam. Its altitude ranges from 1,040 to 2,380 meters above sea level. The average temperature ranges from $14{ }^{\circ} \mathrm{C}$ to $27^{\circ} \mathrm{C}$ while the annual rainfall ranges between 780 and $900 \mathrm{~mm}$. The district is known with its scattered bushes, shrubs and acacia trees (Ferede et al., 2014).

West Hararghe zone is located at $7^{\circ} 50^{\prime}-9^{\circ} 50^{\prime} \mathrm{N} ; 40^{\circ} 00^{\prime}-41^{\circ} 25^{\prime} \mathrm{E}$ and $1200-3060$ meters above sea level. The zone shares boundaries with Afar Regional State, Somali Regional State, as well as the east Hararghe Zone. It has three distinct agro-ecologies that consists of highland (17.5\%), mid highland (28.5\%), and lowland (54.0\%) and have two rainy seasons, the short rainy season and the main rainy season, with a mean annual rainfall ranging from below $700 \mathrm{~mm}$ in the lowlands to nearly $1200 \mathrm{~mm}$ at higher altitudes (Ketema et al., 2018). The farming system is mainly characterized by pastoralism and agro-pastoralism. In addition to other livestock, the zone has high camel breeding potential.

\section{Study population}

The study population included the total number of camels presented to and slaughtered in the abattoir. Camels purchased from different markets were transported to the abattoir by trucks and kept at lairage for 3 to 4 days. Camels in the pastoral area (their original sites) browse on bushes and shrubs, but grasses may be consumed rarely when shrubs or trees are not available. The browse species includes the family Chenopodiaceae, Acacia brevispica, Opuntia ficus indica, Dichrostachys ciniarea and Euphorbia tirucalli (Bekele and Kibebew, 2002). The main sources of water for camels in the areas include wells, ponds and rivers (Wolde, 1991). The watering sites are usually visited 
once per week by large numbers of camels and other animals at a time from the surrounding as well as from distant areas. Mostly the pond and river water sources are shared by wild animals too (Mirkena et al., 2018). Camels in the pastoral areas are used for packing, transportation, ploughing and traction purposes and as source of cash income, milk and meat (Mehari et al., 2007).

\section{Study animals and sample size}

The sample size was calculated using the formula given for simple random sampling (Thrusfield and Brown, 2018) with a previous prevalence of $65 \%$ (Regassa et al., 2015), $95 \%$ confidence level and 5\% desired absolute precision. Accordingly, the sample size was determined to be 350 . However, 66 more camels were included with the intention of maximizing the sample size for better precision. The sampling procedure was carried out using systematic random sampling (Thrusfield and Brown, 2018), whereby every third camel walking into the lairage was selected and marked.

\section{Study methodology}

\section{Antemortem examination}

During each regular visit, all the camels brought for slaughter were inspected while entering into the lariage for the presence of any observable abnormality. The general behavior of the animal, body condition, gait, posture, clinical signs suggestive of disease and abnormality of any type were registered (Gracey et $a l ., 1999)$ and judgment was made based on FAO recommendation (Herenda et al., 1994).

Data about the age, sex, origin and body condition score of the selected camels were recorded before slaughtering. The age of the camels was estimated using rostral dentition (Bello et al., 2013) and then categorized as young (less than 5 years) and adult ( $\geq 5$ years of age) for ease of data analysis. The body condition score of the camels were assessed according to Faye et al., (2001) and then grouped as poor (score 1), medium (score 2 and 3) and good (score 4).

\section{Post Mortem Examination}

Following slaughter and evisceration, a thorough and systematic inspection of the visceral organs particularly the lungs, liver, spleen, heart and kidneys 
were made for presence of hydatid cyst using visual inspection, palpation and multiple incisions, when required. The pathological lesions were differentiated according to guidelines on meat inspection for developing countries (Herenda et $a l ., 1994)$. Cysts of each organ were counted and differentiated as calcified and non-calcified based on their consistency and appearance. The study animals were considered as positive if at least one cyst was found in one or more of the organs examined. All non-calcified hydatid cysts (when the number of cysts in the organ is $\leq 3$ ) and three randomly selected non-calcified hydatid cysts (when their number on the organ is $>3$ ) were collected. Briefly, the non-calcified cysts were removed whole and placed in clean polyethene bags, labeled properly and transported to the laboratory of National Artificial Insemination center (at Kaliti, Addis Ababa) for further examination.

\section{Cyst fertility and viability tests}

The surface of the cyst was wiped off or blotted with tissue paper and/or gauze and then, to reduce intracystic pressure, part of the fluid was drained with a 21-gauge needle attached with a $12 \mathrm{ml}$ syringe. By cutting the cyst wall with scalpel and scissors, the remaining content of the cyst was poured into a clean petri dish. The fertility of the cyst was determined by considering the presence of protoscolices (as white dots on the germinal epithelium or broad capsule or hydatid sands suspended in the fluid) (Urquhart et al., 1996; Bowman, 2014). The cysts which contained no protoscolex as well as suppurative or calcified cyst were considered as non-fertile cyst.

All the fertile cysts were then subjected to viability test. The viability of the protoscolices was assessed by examining them under a microscope (40X) following the application of $0.1 \%$ aqueous eosin solution (Smyth and Barrett, 1980). The protoscolices were considered viable when they didn't take the eosin stain.

\section{Statistical analysis}

All the collected data were entered into Microsoft Excel spreadsheet coded and then analyzed using STATA statistical software (STATA, 2013; window version 13.1). Association between various risk factors (sex, age, origin and body condition score) and the prevalence of hydatidosis was assessed by using chisquare independent test. Moreover, univariable and multivariable logistic regression analyses were carried out to assess the level of significance. In all the analysis, significance was set at $p<0.05$. 


\section{Results}

The overall prevalence of CE in camels in the current study was $38.22 \%$ (159 out of 416 camels). The hydatid cysts were detected more frequently in the lungs (37.02\%) followed by the liver (35.1\%), but very few camels had cysts in other organs (heart, spleen and kidney) (Table 1). Majority of the slaughtered camels had hydatid cysts both in their liver and lungs.

Table 1. Prevalence and organ level distribution of hydatid cysts in the examined camels $(n=416)$.

\begin{tabular}{lccc}
\hline Tissue /organ & No positive & Prevalence (\%) & 95\% CI \\
\hline Lung & 154 & 37.02 & $32.36-41.68$ \\
Liver & 146 & 35.10 & $30.49-39.70$ \\
Kidney & 2 & 0.48 & $-0.19-1.15$ \\
Spleen & 1 & 0.24 & $-0.23-0.71$ \\
Heart & 1 & 0.24 & $-0.23-0.71$ \\
Lung +Liver & 143 & 34.37 & $29.79-38.96$ \\
Lung + Kidney & 2 & 0.48 & $-0.19-1.15$ \\
Over all & 159 & 38.22 & $33.53-42.91$ \\
\hline
\end{tabular}

Relatively higher prevalence and likelihood of occurrence of hydatid cyst were observed in female camels (48.05\%, OR 1.93), in old camels (53.07\%, OR 4.5), camels originated from Kereyu (43.24\%, OR 1.72), and camels with medium body condition ( $67.4 \%$, OR 22.86 ) than in the category/ies of the respective risk factors. With the exception of the origin $(p=0.173)$, the difference in the prevalence of hydatidosis between or among the categories of the other considered risk factors (age, body condition score and sex) were statistically significant ( $p<$ 0.05) (Table 2). 
Table 2. Prevalence and logistic regression analysis of hydatid cyst in camel by the putative risk factors.

\begin{tabular}{|c|c|c|c|c|c|c|}
\hline Variable & & $\begin{array}{l}\text { № } \\
\text { exam } \\
\text { ined }\end{array}$ & $\begin{array}{l}\text { № }(\%) \\
\text { positive }\end{array}$ & $\begin{array}{l}\text { Crude OR } \\
(95 \% \text { CI })\end{array}$ & $\begin{array}{l}\text { Adjusted OR } \\
(95 \% \text { CI) }\end{array}$ & $p$-value \\
\hline \multirow[t]{2}{*}{ Age group } & Young & 188 & $38(20.21)$ & 1 & 1 & \\
\hline & Adult & 228 & $121(53.07)$ & $4.5(2.9-6.9)$ & $3.7(2.21-6.12)$ & 0.000 \\
\hline \multirow[t]{3}{*}{$\mathrm{BCS}$} & Poor & 104 & $8(7.69)$ & 1 & 1 & \\
\hline & Medium & 172 & $116(67.44)$ & $22.86(11.29-54.69)$ & $35.6(14.4-88.02)$ & 0.000 \\
\hline & Good & 140 & $35(25.00)$ & $4.0(1.77-9.05)$ & $4.7(2.01-11.10)$ & 0.000 \\
\hline \multirow[t]{2}{*}{ Sex } & Male & 262 & $85(32.44)$ & 1 & 1 & \\
\hline & Female & 154 & $74(48.05)$ & $1.93(1.28-2.90)$ & $1.95(1.10-3.47)$ & 0.023 \\
\hline \multirow[t]{4}{*}{ Origin } & Borana & 101 & $31(30.69)$ & 1 & 1 & \\
\hline & Kereyu & 111 & $48(43.24)$ & $1.72(0.98-3.03)$ & $1.64(0.80-3.34)$ & 0.173 \\
\hline & $\begin{array}{l}\text { Minjar } \\
\text { Shenkora }\end{array}$ & 92 & $34(36.96)$ & $1.32(0.73-2.41)$ & $1.25(0.60-2.60)$ & 0.558 \\
\hline & $\begin{array}{l}\text { West } \\
\text { Hararghe }\end{array}$ & 112 & $46(41.07)$ & $1.57(0.89-2.77)$ & $1.32(0.65-2.66)$ & 0.446 \\
\hline
\end{tabular}

$\overline{\mathrm{BCS}}=$ Body Condition Score, $\mathrm{OR}=$ Odds Ratio, $\mathrm{CI}=$ Confidence Interval

Out of 768 cysts collected from the different organs, 169 (22\%), 215 (28\%) and $384(70.57 \%)$ were found to be abscessated / calcified, sterile and fertile cysts, respectively. The proportion of fertile cysts was higher in the lungs $(54.4 \%)$ followed in the liver (45.12\%) and kidneys (20\%). Of the fertile cysts collected from lungs and liver, 146 (62.13\%) and 87 (58.78\%) were viable. However, all the cysts collected from kidneys, spleen and heart were non-viable (Table 3).

Table 3. Cyst fertility and viability in different organs of study camels

\begin{tabular}{|c|c|c|c|c|c|}
\hline Organ & $\begin{array}{l}\text { No of collected } \\
\text { cysts }\end{array}$ & $\begin{array}{l}\text { Sterile cyst } \\
\text { No }(\%)\end{array}$ & $\begin{array}{l}\text { Calcified cysts } \\
\text { No }(\%)\end{array}$ & $\begin{array}{l}\text { Fertile } \\
\text { cyst } \\
\text { No (\%) }\end{array}$ & $\begin{array}{l}\text { Viable cysts } \\
\text { No (\%) }\end{array}$ \\
\hline Lung & 432 & $110(25.46)$ & 87 (20.14) & $235(54.40)$ & $146(62.13)$ \\
\hline Liver & 328 & $102(31.10)$ & 78 (23.78) & $148(45.12)$ & 87 (58.78) \\
\hline Kidney & 5 & $1(20)$ & $3(60)$ & $1(20)$ & 0 \\
\hline Spleen & 2 & $1(50)$ & $1(50)$ & 0 & 0 \\
\hline Heart & 1 & 1(100) & 0 & 0 & 0 \\
\hline Over all & 768 & $215(28.0)$ & $169(22.0)$ & $384(70.57)$ & $231(60.16)$ \\
\hline
\end{tabular}




\section{Discussion}

The prevalence of camel hydatidosis recorded in this study (38.22\%) is relatively higher than the previous reports $23 \%$ by Debela et al. (2015), $28.7 \%$ by Hayer et al. (2014), 22.6\% by Muskin et al. (2011) and 18.8\% by Woldemeskel et al. (2001) from different parts of Ethiopia. However, comparably higher prevalence (61.4 to $65 \%$ ) than the current study was also reported in Ethiopia (Regassa et al., 2015; Boru et al., 2013). Higher prevalence values were also reported from other African countries such as $61.4 \%$ from Kenya (Njoroge et al., 2002), 45\% from Sudan (Elmahdi et al., 2004) and $44.4 \%$ from Nigeria (Okolugbo et al., 2013). The prevalence difference observed between these studies could be partly explained by the difference in the ecology, husbandry, livestock stocking intensity, population of the definitive hosts and the sociocultural practices. Specifically, the most common production practices that may increase the risk of exposure of farm animals to hydatidosis include improper disposal of dead animals, the access of dogs to the offals of slaughtered animals, absence of regular deworming of dogs, communal and mixed-species grazing, and unrestricted use of watering points by camels, stray dogs and other wild canidae (Azlaf and Dakkak, 2006; Christodoulopoulos et al., 2008; Elham et al., 2014).

The prevalence of hydatidosis was significantly higher in female camels (OR $1.95, p=0.023$ ) than the males and in old camels (OR 3.7, $p=0001$ ) than young camels. This finding is in line with the reports of Muskin et al. (2011), Gizachew et al. (2013), Boru et al. (2013) and Debela et al. (2015) from Ethiopia, Abdul-Salam and Farah (1988) from Kuwait, Ibrahim et al. (2011) from Sudan and Elham et al. (2014) from Iran. These might be related to the higher chance of direct or indirect contact with freely roaming dogs while the female camels are brought and kept around the homesteads till they get milked. Moreover, as female animals are kept for prolonged years for milk production, the possibility of acquiring and sustaining infections will also increase. Given the high reproductive capacity of Echinococcus granulosus, a single infected dog can excrete feces with a large number of parasite's eggs that can contaminate wide range of the foraging areas and watering points (Gemmell, 1990; Parija, 2004).

In the present study, the hydatid cysts were detected more frequently in the lungs (37.02\%) followed by the liver (35.1\%). Comparable reports were also made previously from Ethiopia (Woldemeskel et al., 2001; Muskin et al., 2011; Gizachew et al., 2013; Debela et al., 2015) and elsewhere (Anwar and Khan, 
1998; Ibrahim and Craig, 1998; Sharrif et al., 1998; Njoroge et al., 2002; Ahmadi, 2005; Okolugbo et al., 2013; Elham et al., 2014). In contrary, Ibrahim (2010) from Saudi Arabia and Boru et al. (2013) and Hayer et al. (2014) from Ethiopia reported that the liver is more frequently affected organ than the lungs. In the current study, it is also noted that concurrent infection of both liver and lungs was equally common like infection of either of the organs alone.

The higher frequency of infection in lungs and liver might be due to the fact that the migrating echinococcus oncospheres that get into the subepithelial capillaries of the intestine or the lacteal has to pass first the great capillary bed of the hepatic and pulmonary filtering system before reaching any other organ (Brown et al., 2007; Kebede et al., 2009). Owing to the largest capillary beds in the lungs, oncospheres entering the vena cava with the lymph will be first filtered out and trapped in the lung and concomitantly forms the cyst than in any other organ (Brown et al., 2007).

The infectivity potential of the cysts revealed that $70.57 \%$ of the cysts were fertile, of which $60.16 \%$ were viable, which is in line with Muskin et al. (2011) and Okolugbo et al. (2013) who reported 50\% and 79\% fertility in camels from Ethiopia and Nigeria, respectively. Although not statistically significant, cysts from the lungs were more fertile and viable than the liver. In Ethiopia, Muskin et al. (2011), Boru et al. (2013) and Hayer et al. (2014) also reported relatively more fertile cysts from lungs than the liver. On the contrary, the studies conducted by Elham et al. (2014) in Iran and Ibrahim et al. (2011) in Sudan showed that hydatid cysts of the liver have higher fertility rate than that of lungs. Our observation can be explained by the relative softer consistency of the lung tissue, compared to liver, which might favor the development of the cyst and hence make them fertile.

\section{Conclusions}

The present study disclosed that high prevalence of camel $\mathrm{CE}$ with a higher proportion of fertile and viable cysts indicating a serious public health concern particularly in the study areas. Therefore, timely efforts should be made to control the transmission of cystic echinococcosis through extension work on safe disposal of infected offal and dead animals, awareness creation to the community about the disease, construction of abattoirs with appropriate disposal pits and introducing strict meat inspection protocols. Moreover, molecular based study should be conducted to identify the prevailing strains/genotype of E. granulosus in the area. 


\section{Acknowledgements}

We would like to thank workers at Addis Ababa abattoir enterprise Akaki branch and the technical staff of the Parasitology and Pathology laboratory of the Faculty of Veterinary Medicine, Hawassa University for their cooperation during sample collection and support during sample processing, respectively. Special thanks also go to the Addis Ababa abattoir enterprise Akaki branch for allowing us to work in the premises. This research did not receive any specific grant from funding agencies in the public, commercial, or not-for-profit sectors.

\section{Conflict of interest}

The authors declare that they have no competing interests. This piece of work has not been published previously or not submitted for publication elsewhere. The submission is approved by all authors and all the authors declare that they have no conflict of interest.

\section{References}

Abbas, B., Saint-Martin, G. and Planchenaut, D., 1993. Constraint to camel production in Eastern Sudan: a survey of pastoralist conception. Sudan J. Vet. Sci. Anim. Husb., 32, 31-41.

Abdul-Salam, J.M. and Farah, M.A., 1988. Hydatidosis in camels in Kuwait. Parasitol. Res.,74, 267-270.

Acosta-Jamett, G., Cleaveland, S., Cunningham, A.A., Bronsvoort, B.M. and Craig, P.S., 2010. Echinococcus granulosus infection in humans and livestock in the Coquimbo region, north-central Chile. Vet. Parasitol., 169, 102-110.

Ahmadi, N.A., 2005. Hydatidosis in camel (Camelus dromedarius) and their potential role in the epidemiology of Echinococcus granulosus in Iran. J. Helminthol., 79, 119-125.

Anwar, A.H. and Khan, M.N., 1998. Parasitic fauna of camel in Pakistan. In: The proceedings of the third annual meeting for animal production under arid conditions, United Arab Emirates University. pp 69-76.

Azlaf, R. and Dakkak, A., 2006. Epidemiological study of the cystic echinococcosis in Morocco. Vet. Parasitol., 137, 83-93.

Bekele, T. and Kibebew, T., 2002. Camel production and productivity in eastern lowlands of Ethiopia. In: Livestock in food security - roles and contributions, Addis 
Ababa: Proceedings of the $9^{\text {th }}$ conference of the Ethiopian Society of Animal Production, pp 145-161.

Bello, A., Sonfada, M.L., Umar, A.A., Umaru, M.A., Shehu, S.A., Hena, S.A., Onu, J.E. and Fatima, O.O., 2013. Age estimation of camel in Nigeria using rostral dentition. Sci. J. Anim. Sci.,2, 9-13.

Beyene, S. and Gudina, D., 2009. Reviving a Traditional Pasture Management System in Fentale, East Central Ethiopia. J. Ecolog. Anthrop., 13, 57-72.

Boru, B.G., Tolossa, Y.H., Tilahun, G. and Ashenafi, H., 2013. Study on prevalence of hydatidosis and cyst characterization in camels (Camelus dromedarius) slaughtered at Akaki abattoir, Ethiopia. J. Vet. Med. Anim. Hlth., 5, 329-333.

Bowman D.D., 2014. Georgis' Parasitology for Veterinarians. Saunders - an imprint of Elsevier, St. Louis, Missouri, $10^{\text {th }}$ Edition, pp 149-150.

Brown, C.C., Baker, D.C. and Barker, I.K., 2007.Alimentary system. In: Maxie, M.G. (Ed.), Jubb, Kennedy, and Palmer's pathology of domestic animals, Vol 1, $5^{\text {th }} \mathrm{ed}$. Elsevier, Philadelphia, pp 257-258.

Christodoulopoulos, G., Theodoropoulos, G. and Petrakos, G., 2008. Epidemiological survey of cestode-larva disease in Greek sheep flocks. Vet. Parasitol., 153, 368-573.

Craig, P.S., 1997. Immunodiagnosis of Echinococcus granulosus and a comparison of techniques for diagnosis of canine echinococcosis. In: Andersen, F.L., Ouhelli, H. and Kachani, M. (Eds.), Compendium on Cystic Echinococcosis in Africa and in Middle Eastern Countries with Special Reference to Morocco, Brigham Young University, Provo, UT, pp 85-118.

Dakkak, A., 2010. Echinococcosis/hydatidosis: A severe threat in Mediterranean countries. Vet. Parasitol., 174, 2-11.

Dalimi, A., Motamedi, Gh., Hosseini, M., Mohammadian, B., Malaki, H., Ghamari, Z. and Far, G.F., 2002. Echinococcosis/hydatidosis in western Iran. Vet. Parasitol., $105,161-171$.

Debela, E., Abdulahi, B. Megersa, B., Kumsa, B., Abunna, F., Sheferaw, D. and Regassa, A., 2015. Hydatidosis of camel (Camelus dromedarius) at Jijiga municipal abattoir, Eastern Ethiopia: prevalence, associated risk factors and financial implication. J. Parasit. Dis., 39, 730-735.

Elham, M., Hassan, B., Ghasem, N.A., Gholamreza, R. and Parviz, S., 2014. Epidemiological study of hydatidosis in the dromedaries (Camelus dromedarius) of different regions of Iran. Asian Pac. J. Trop. Biomed.,4(Suppl 1): S148-S151. 
Elmahdi, I.E., Ali, Q.M., Magzoub, M.M.A., Ibrahim, A.M., Saad, M.B. and Romig, T., 2004. Cystic echinoccosis of livestock and humans in central Sudan. Ann. Trop. Med.Parasit., 98, 473- 79.

Faye, B., Bengoumi, M., Cleradin, A., Tabarani, A. and Chilliard, Y., 2001. Body condition score in dromedary camel: A tool for management of reproduction. Emir. J. Agric.Sci.,13, 1-6.

Ferede, S., Yigezu, Y.A., Kemal, S. .and Aw-Hassan, A., 2014. Trends in global and national grain legume production and trade: Implications on local chickpea and lentil production dynamics: The case of Gimbichu and Minjar-Shenkora districts of Ethiopia. ICARDA. Science for better livelihood in Dry land, pp 6-8.

Galma, W., 2015. Economic value of camel milk in pastoralist communities in Ethiopia: Findings from Yabello district, Borana zone. IIED Country Report. IIED, London, pp 3-19.

Gemmell, M.A., 1990. Australasian contributions to an understanding of the epidemiology and control of hydatid disease caused by Echinococcus granulosus past, present and future. Int. J. Parasitol.,20, 431-456.

Gizachew, B., Kibru, F., .and Asrade, B., 2013. Camel hydatidosis: prevalence and economic significance in pastoral regions of Ethiopia. J. Parasitol. Vector Biol., 5, 90-95.

Gracey, J.F., Collins, D.S. and Huey, R.J., 1999. Meat Hygiene, $3^{\text {rd }}$ ed. WB Saunders Company Ltd., pp 669-678.

Hayer, A.M., Kebede, M.C., and Warsame, I., 2014. Prevalence, Economic and Public Health Significance of Camel Hydatidosis in Dire Dawa Municipal Abattoir, Eastern Ethiopia. Acta Parasitol. Glob., 5, 98-106.

Herenda, D., Chambers, P.G., Ettriqui, A., Seneviratna, P. and Da Silva, T.J.P., 1994. Manual on meat inspection for developing countries, FAO, Rome.

Ibrahim, K., Thomas, R., Peter, K. and Omer, R.A., 2011. A molecular survey on cystic echinococcosis in Sinnar area, Blue Nile state (Sudan). Chin. Med. J., 124, 2829 2833.

Ibrahim, M.M., and Craig, P.S., 1998. Prevalence of cystic echinococcus in camels (Camelus dromedarius) in Libya. J. Helminthol.,72, 27-31.

Ibrahim, M.M., 2010. Study of cystic echinococcosis in slaughtered animals in Al Baha region, Saudi Arabia: Interaction between some biotic and abiotic factors. Acta Tropica, 113, 26-33.

Ito, A., Urbani, C., Jiamin, Q., Vuitton, D.A., Dongchuan, Q., Heath, D.D., Craig, P.S., Zheng, F. and Schantz, P.M., 2003. Control of echinococcosis and cysticercosis: a 
public health challenge to international cooperation in China. Acta Tropica, 86, 3-17.

Kebede, N., Mekonnen, H., Wossene, A. and Tilahun, G., 2009. Hydatidosis of slaughtered cattle in Wolaita Sodo Abattoir, Southern Ethiopia. Trop. Anim. Hlth. Prod., 41, 629-633.

Keskes, S., Dejen, T., Tesfaye, S., Fekadu, R., Tesfu, K. and Fufa, D., 2013. Characterization of Camel Production System in Afar Pastoralists, North East Ethiopia. Asian J. Agric. Sci.,5, 16-24.

Ketema, B., Bekele, B., Kifle, N. and Shimalis, A., 2018. Prevalence of Bovine Mastitis, Risk Factors and major Causative Agents in West Hararghe Zone, East Ethiopia. East Afr. J. Vet. Ani. Sci., 2, 1-10.

Latif, A.A., Tanveer, A., Maqbool, A., Siddiqi, N., Kyaw-Tanner, M. and Traub, R.J., 2010. Morphological and molecular characterization of Echinococcus granulosus in livestock and humans in Punjab, Pakistan. Vet. Parasitol., 170, 44-49.

Mehari, Y., Mekuriaw, Z. and Gebru, G., 2007. Potential of camel production in Babilie and Kabrebiyah woreds of Jijiga zone, Somali Region, Ethiopia. Livestock Research for Rural Development, Volume 19, Article \#58. Retrieved Nov.14, 2019, from http://www.irrd.org/irrd19/4/meha19058.htm

Mirkena, T., Walelign, E., Tewolde, N., Gari, G., Abebe, G. and NewmanS., 2018. Camel production systems in Ethiopia: a review of literature with notes on MERSCoV risk factors. Pastor. Res. Policy Pract., 8:30. 17pp. https://doi.org/10.1186/s13570018-0135-3.

Muskin, S., Hailu, D. and Moti, Y., 2011. Infection Rates, Cyst Fertility and Larval Viability of Hydatid Disease in Camels (Camelus dromedarius) from Borena, Kereyu and Harar Areas of Ethiopia. Glob. Vet., 7, 518-522.

Njoroge, E.M., Mbithi, P.M.F., Gathuma, J.M., Wachira, T.M., Gathura, P.B., Magambo, J.K. and Zeyhle, E., 2002. A study of cystic echinococcosis in slaughter animals in three selected areas of northern Turkana, Kenya. Vet. Parasitol., 104, 85-91.

Okolugbo, B.C., Luka, S.A. and Ndams, I.S., 2013. Hydatidosis of camels and cattle slaughtered in Sokoto State, Northern Nigeria. Food Sci. Qual. Manag., 21, 40-46.

Omer, R.A., Dinkel, A., Romig, T., Mackenstedt, U., Elamin, M., Elnahas, A., Aradaib, I.E., Ahmed, M.E., Elmalik, K.H. and Adam, A., 2004. Strain Characterization of Human Hydatidosis in Sudan. Int. Arch. Hydatid., 35, 41.

Oryan, A., Moghaddar, N. and Gaur, S.N., 1994. Metacestodes of sheep with special reference to their epidemiological status, pathogenesis and economic implications in Fars province. Iran. J. Parasitol.,51, 231-240. 
Parija, S.C., 2004. Medical Parasitology, Protozoology and Helminthology text and Atlas, $2^{\text {nd }}$ ed. Medical Books Publisher, Chennai, pp 221-229.

Regassa, A., Awol, N., Hadush, B., Tsegaye, Y. and Sori, T., 2015. Internal and external parasites of camels (Camelus dromedarius) slaughtered at Addis Ababa Abattoir, Ethiopia. J. Vet. Med. Anim. Hlth.,7, 57-63.

Salih, M., Degefu, H. and Yohannes, M., 2011. Infection Rates, Cyst Fertility and Larval Viability of Hydatid Disease in Camels (Camelus dromedarius) from Borena, Kereyu and Harar Areas of Ethiopia. Global Vet., 7 (6), 518-522.

Sharrif, L., AL-Rawashdeh, O.M., Al-Qudah, K.M. and Al-Ani, F.K., 1998. Prevalence of gastrointestinal helminthes, hydatid cysts and nasal myiasis in camel in Jordan. In: The proceeding of the third annual meeting for animal production under arid conditions. United Arab Emirates, pp 108-114.

Smyth, J.D. and Barrett, N.J., 1980. Procedure for testing the viability of human hydatid cyst following surgical removal, especially after chemotherapy. Trans. $R$. Soc. Trop. Med. Hyg., 74, 649-652.

SOS-Sahel Ethiopia, 2007. Pastoralism in Ethiopia: Its total economic values and development challenges. Project Evaluation Report: Oxfam Canada, Addis Ababa, pp 2-17.

Tefera, M. and Abebe, G., 2012. Camels in Ethiopia, $1^{\text {st }}$ edition, Ethiopian Veterinary Association, pp 91-98.

Thrusfield, M. and Brown, H., 2018. Survey. In: Thrusfield, M. (Ed.), Veterinary Epidemiology, fourth ed. Hoboken, NJ: Wiley. Pp 275-277.

Urquhart GM, Armour J, Duncan JL, Dunn AM, Jennings FW (1996) Veterinary Parasitology, 2nd edn. Blackwell Science Ltd., London, pp 120-130

Volpato, G., Saleh, S.M.L. and Di Nardo, A., 2015. Ethnoveterinary of Sahrawi pastoralists of Western Sahara: camel diseases and Remedies. J. Ethnobiol. Ethnomed.,11, 54.

Wolde, A., 1991. Traditional husbandry practices and major health problems of camels in the Ogaden (Ethiopia). Nomadic Peoples, 29, 21-30.

Woldemeskel, M., Issa, A., Mersie, A. and Potgieter, L.N.D., 2001. Investigation of parasitic disease of one-humped camel (Camelus dromedarius) in eastern Ethiopia. J. Camel Pract. Res.,8, 77-81.

Zeleke, M. and Bekele, T., 2000. Camel herd health and productivity in Eastern Ethiopia selected semi-nomadic households. Revue d'élevage et Médecine Vétérinaire des pays Tropicaux 53 (2), 13-217.

Ethiop. Vet. J., 2021, 25 (1), 43-57 